\title{
Emotional Coregulation Patterns of Romantic Partners
}

\author{
Romantik Partnerlerin Duygusal Ortak Düzenleme Örüntüleri
}

\section{Elçin GÜNDOĞDU AKTÜRK * Bülent AYKUTOĞLU **}

\begin{abstract}
This study aims to examine the coregulation patterns in the positive and negative affect of normative romantic partners and to replicate the previous findings in the emotion regulation field. For this aim, 37 romantic couples (74 individuals) completed daily records for 14 consecutive days. We hypothesized that one's daily positive/negative affect would be positively associated with the partner's daily positive/negative affect. We also expected that changes in one's daily positive/negative affect would be positively associated with changes in the partner's daily positive/negative affect. The hypothesis was partially supported, as results of multilevel analyses revealed that partners' daily positive and negative affect positively predict one's own positive and negative affect. Moreover, change in partners' positive affect positively predicted one's own change in positive affect. Change in partners' negative affect did not predict one's own change in negative affect. Overall, the findings demonstrated the coregulation pattern in positive affect but not for negative affect for romantic dyads. The findings made an important contribution to the field of emotion regulation by replicating previous findings and providing further evidence for the emotional coregulation of romantic couples.
\end{abstract}

Keywords: Coregulation, Positive and Negative Affect, Romantic Partners, Diary Study

$\ddot{O}_{z:} \mathrm{Bu}$ çalışmanın amacı, normatif romantik partnerlerin olumlu ve olumsuz duygulanımlarında ortak düzenleme (coregulation) örüntülerini incelemek ve duygu düzenleme alanındaki önceki bulguları tekrarlamaktır. Bu amaçla, 37 romantik çift (74 kişi) ardışık 14 gün boyunca günlük kayıtları tamamlamıştır. Hipotezimiz, kişinin günlük olumlu / olumsuz duygularının, partnerinin günlük olumlu / olumsuz duygularıyla olumlu bir şekilde ilişkili olacağı idi. Ayrıca, kişinin kendi olumlu / olumsuz duygularındaki günlük değişimlerin, partnerinin olumlu / olumsuz duygularındaki günlük değişimlerle pozitif olarak ilişsili olacağı idi. Hipotez kısmen desteklenmiş, çok düzeyli analizlerin sonuçları partnerlerin günlük olumlu ve olumsuz duygularının, kişinin kendi olumlu ve olumsuz duygularını pozitif olarak yordadığını göstermiştir. Ayrıca, partnerlerin olumlu duygularındaki günlük değişimler ise, kişinin kendi olumlu duygularındaki günlük değişimlerini pozitif yönde yordamıştır. Ancak partnerlerin olumsuz duygularındaki günlük değişimler, kişinin kendi olumsuz duygularındaki değişimlerle ilişkili bulunmamıştır. Sonuç olarak, bulgular ortak düzenleme örüntüsünü olumlu duygular için desteklerken olumsuz duygular için desteklememektedir. Bu sonuçlar, önceki bulguları tekrarlayarak ve romantik çiftlerin duygusal ortak düzenleme çalışmalarına daha fazla kanıt sağlayarak, duygu düzenleme alanına önemli bir katkı sağlamıştır.

Anahtar kelimeler: Ortak Düzenleme, Olumlu ve Olumsuz Duygulanım, Romantik Çiftler, Günlük Çalışması

* Dr. Öğr. Ü., Zonguldak Bülent Ecevit Üniversitesi, Fen-Edebiyat Fakültesi, Psikoloji Bölümü, Zonguldak. elcin.akturk@beun.edu.tr, https://orcid.org/0000-0002-9322-5668

** Arş. Gör., Orta Doğu Teknik Üniversitesi, Fen-Edebiyat Fakültesi, Psikoloji Bölümü, Ankara. baykutog@metu.edu.tr, https://orcid.org/0000-0003-4288-7546 
Emotions are reactions to a constantly changing world, and most emotions take place within the context of social interactions or relationships (Butler 2015, 1). More specifically, emotions play a significant role in developing and maintaining close relationships (Schoebi \& Randall 2015, 1) by motivating people to form intimate bonds, organize subsequent interactions and inform the intimate partners' each other's relational needs (Keltner \& Haidt 1999, 510). Since close relationships are predicated on high physical, cognitive, and emotional closeness between partners (Schoebi \& Randall 2015, 1); the regulation of the emotions is not just an individual process but also influenced by social interactions with intimate partners (Sbarra \& Hazan 2008, 157; see Butler 2011). For instance, social partners' emotions become coordinated and stimulate each other during arguments or love affairs (Butler 2015, 1). Regulation of these interpersonal processes such as ability to affect the occurrence, duration, and intensity of emotions has a pivotal role in psychological and relationship functioning (Diamond \& Aspinwall 2003, 147; Butler \& Randall 2013, 202) and has implications for individual well-being (Reis, 2013). Indeed, all sorts of emotional reactions generated within close relationships motivate and direct relational behaviors (Schoebi \& Randall 2015, 5; Butler 2017, 131-132). In other words, each partner's emotional responses to relational needs, and their partner's feedback contribute to the coordination of further interactions. Furthermore, high-quality affective relationships were found to be linked with a range of positive health consequences for relationship partners (Sbarra \& Coan 2018, 41). Recently, the importance of affective reactivity, defined as individual's within-person associations between daily stress and affect, for married couples were shown in a longitudinal study as emotional reactions and emotion regulation capacity tend to give shape marital processes (Ong et al. 2019). The results of the study revelaed not only that the heightened affective reactivity predicts lower marital quality but also physiological correlates of it. Thus, it can be concluded that emotional reactions and regulation of the reactivities are directly linked with the relational processes.

In the child development field, the interpersonal emotion regulation phenomenon called "coregulation" refers to a dyadic emotional system of an adult and infant, and co-constructing optimal affective states during social interactions (Tronick 1989; Feldman 2003, 3). A growing body of literature has investigated this adult-child emotional regulation system (e.g. Feldman 2015; Lunkenheimer et al. 2015; Beebe et al. 2016). However, there has been less research attention directed toward emotion coregulation and its effects on interpersonal processes for adults (Butler \& Randall 2013, 1). In the limited work, the way romantic relationships contribute to emotion regulation (e.g., Beckes \& Coan 2011; Zaki \& Williams 2013) and implications of emotional experiences for intimate relationships (e.g., Reis \& Shaver 1988; Gottman 1993; Bradbury et al. 2000) were the most widely studied topics (Schoebi \& Randall 2015, 1-2). Recently, dyadic patterns of emotion regulation in romantic relationships were more a topic of inquiry. In these studies, associations of physiological signals within romantic couples (e.g., Helm et al. 2012; Reed et al. 2013), the relationship between attachment styles and emotion transmission, and dyadic patterns of emotion coordination and cooperation (Randall \& Butler 2013,6) were investigated. Although these studies shed light on the dyadic nature of emotion regulation in romantic relationships, more research for emotion coregulation in adult literature, especially for romantic couples, can still provide useful information on interdependence in partners' emotional changes.

\section{Coregulation}

Coupling patterns of emotions for dyads has been defined by different scholars and investigated by using different methods. From an attachment theory perspective, coregulation is reciprocally keeping psychophysiological homeostasis within a relationship (see Sbarra \& Hazan 2008). As a proper and emergent feature of all clear-cut attachment relationships, emotional and physiological coregulation has an adaptive value for individuals (Hazan et al. 2004). In another 
view, coregulation is defined as a kind of balanced state that includes people's affective oscillations mutually converging towards a stable state or diverging away from that state (Butler \& Randall 2013, 203; Butler 2015, 1).

There have been studies which have supportive findings about coupling patterns of emotions within romantic relationships. In one of the preliminary works for the coregulation using physiological measurements for romantic couples, a positive link among romantic dyads' cortisol levels was found (Saxbe \& Repetti 2010). Also, although individuals' positive mood did not predict their partners' positive or negative mood, their negative mood predicted partners' negative mood (Saxbe \& Repetti 2010, 96-98). In another study, it was found that emotional reactions of romantic dyads became more similar within time (Anderson et al. 2003, 1057-159). Further, romantic partners' daily levels of positive and negative affect covaried, after controlling for the positivity or negativity of partners' daily interactions (Butner et al. 2007, 438-450). In addition to this, dual smoker romantic couples' emotional experiences also converged during an experimental study (Rohrbaugh et al. 2009, 61-63). These findings suggested a coregulation pattern referring bidirectional linkage of oscillating affective transmission between partners.

Attachment theory emphasizes biological interdependence when defining coregulation concept (see Sbarra \& Hazan 2008), and prior work present evidence for coregulation in romantic partners, as romantic couples demonstrate positive partner effects on heart rate variability (Helm et al. 2012; 2014). Heart rate variability is mostly as an index of emotion regulation capacity and flexibility, and it was argued that the emotional interdependence of romantic couples is not only important for relational behaviors but also may have health protective function (Sbarra \& Coan 2018, 43).

\section{The Current Study}

Although previous studies achieved to show coregulation patterns of romantic couples (e.g., Butner et al. 2007; Diamond et al. 2008; Steele \& Ferrer 2011; Randall \& Butler 2013; Sels et al. 2016), there are empirical contradictions in those studies. For instance, in one study, married couples showed covariation only in negative emotional experience (Saxbe \& Repetti 2010). However, in another study only women's daily positive affect was influenced by partner's positive affect, whereas there was no association among partners' negative affect (Steele \& Ferrer 2011,977-980). Moreover, in one study, only $36 \%$ of the couples demonstrated noteworthy emotional interdependence (Sels et al. 2016, 5-9). Prior work highlighted that findings regarding interpersonal emotional dynamics are often complex and ambiguous, and tried to clarify the theoretical side of the topic and make an effort to explain these empirical contradictions by reconceptualizing emotional (inter)connectedness (Butler 2015, 4; 2017, 132). Another explanation for these contradictions might be that notable portions of the findings regarding coregulation come from clinical and/or non-normative couples (e.g., long-distance couples, couples in which one or both of the partners have physical or psychological illnesses) (Fisher et al. 2017). Hence, there is still need for more evidence to demonstrate the nature of this interpersonal temporal system over time, starting with normative couples' daily lives. Thus, the primary aim of this paper is to investigate coregulation of normative romantic partners' (i.e., heterosexual romantic relationships including physically and psychologically healthy partners) emotions.

Although there is a growing body of work on coregulation in the literature, research on dyadic patterns of emotional interdependence in couples in Turkish culture is rather scarce. To better understand close relationships and interpret relational behaviors and interconnecting emotions of romantic partners within Turkish culture, more research is preferred. Hence, the other major importance of this study is that it investigates coregulation in a Turkish sample. 
Since previous work (Butler 2011, 20; 2017, 1) suggested the methods of providing interdependence between two partners' changes over time to understand emotions coupled between partners and emotions' nature of interpersonal temporal systems, a daily diary method was used for the present study. This method was used in previous studies (Butner et al. 2007; Diamond et al. 2008; Randall \& Butler 2013), and the clearest example of emotion coregulation came from Butner and colleagues' (2007) work. In their work, 48 couples participated in a 21day diary study and coregulation for both positive affect and negative affect was observed. We followed a similar research design and conducted a 14-day dyadic diary study to try to replicate these previous findings. We also followed a similar operationalization of coregulation as in previous work (Butner et al. 2007), which is the daily association in partners' levels of positive and negative affect, and association of changes in partners' daily positive and negative affect. In this regard, our hypothesis was as follows:

Hypothesis: One's daily positive/negative affect is positively associated with partner's daily positive/negative affect. Also, changes in one's daily positive/negative affect is positively associated with changes in partner's daily positive/negative affect.

\section{Method}

\section{Participants}

We planned to collect data from university students and their romantic partners for two semesters. A total of 39 heterosexual couples (78 individuals) in a romantic relationship for at least six months participated in the study. Participants were recruited from undergraduate courses at a state university in Ankara, and one partner from each couple received bonus points in their courses for participation. 4 participants were excluded from the sample, as they failed to complete baseline questionnaires or at least 3 daily records. 37 couples (74 individuals) completed the study. While mean age for females was $21.6(S D=2.05)$, mean age for males was $22.89(S D=3.83)$. Relationship duration of the couples ranged between 8 months and 60 months $(M=21.32, \mathrm{SD}=14.91)$.

\section{Procedure}

There were two phases in the study: an orientation session, and diary records for 14 consecutive days. In the orientation session, participants received identification codes and detailed information on completing diary records. They also completed a questionnaire package that included demographic information and person-level measures. The diary phase began the day after participants completed the baseline questionnaire package. Participants completed short, online records about their positive and negative affective states at the end of each day throughout 14 consecutive days. Number of completed records on average was $13.05(S D=.91)$ for females, and $12.84(S D=1.19)$ for males.

\section{Measures}

\section{Daily Positive and Negative Affect Schedule}

We measured positive and negative affect with Positive and Negative Affect Schedule (PANAS) (Watson et al. 1988). The scale consists of 10 positive affective states (PA) (e.g. interested, excited, enthusiastic, and proud) and 10 negative affective states (NA) (e.g. upset, guilty, scared, hostile, and afraid). Participants rated the extent to which they experienced each state on a 1 (not at all) to 5 (extremely) scale. We within-person centered the scale items before computing daily reliabilities to remove the between-person effects. Daily reliabilities for positive affect ranged from .89 to .94 , and the mean Cronbach alpha for the 14-day period was .92. Daily reliabilities for negative affect ranged from .90 to .94 , and the mean Cronbach alpha for the 14-day period was .92. In addition to these reliabilities, within-person reliability scores of positive affect and negative affect were calculated, following prior work (Cranford et al. 
2006; Gök et al. 2019). Within-person reliability for positive affect was found as .85, and for negative affect as .83 .

\section{Data Analytic Strategy}

The data used in the present study was hierarchically nested, and it was suitable for multilevel analysis as the assumptions of normality and homoscedasticity were met. We used a multilevel model with two random intercepts and two random slopes (Bolger \& Shrout 2007) to analyze the data and have separate estimates for females and males. We multiplied the female dummycoded variable ( 1 for females and 0 for males) and the male dummy coded variable ( 1 for males and 0 for females) by a predictor to achieve these separate estimates. We reported female estimate using $b f$, and male estimate with $b m$.

To estimate the coefficients, we used SPSS 24 software. In daily analyses, day-level predictors were within-person centered and reported regression coefficients are unstandardized. In analyses with change scores, reported regression coefficients are standardized.

\section{Results}

\section{Results for Coregulation}

To test whether emotional coregulation exists among couples, we first examined whether partner's daily positive and negative affect was associated with one's own daily positive and negative affect, using models with two random intercepts and two random slopes. The equations for the models were as follows:

$$
\begin{aligned}
& \mathrm{PA}_{\mathrm{it}}=\text { female dummy }_{\mathrm{it}}\left[\pi_{\mathrm{f} 0 \mathrm{i}}+\pi_{\mathrm{mli}}(\mathrm{PA})_{\mathrm{it}}\right]+\text { male dummy }_{\mathrm{it}}\left[\pi_{\mathrm{m} 0 \mathrm{i}}+\pi_{\mathrm{fli}}(\mathrm{PA})_{\mathrm{it}}\right] \\
& \mathrm{NA}_{\mathrm{it}}=\text { female dummy }{ }_{\mathrm{it}}\left[\pi_{\mathrm{f} 0 \mathrm{i}}+\pi_{\mathrm{m} 1 \mathrm{i}}(\mathrm{PA})_{\mathrm{it}}\right]+\text { male dummy }{ }_{\mathrm{it}}\left[\pi_{\mathrm{m} 0 \mathrm{i}}+\pi_{\mathrm{fli}}(\mathrm{NA})_{\mathrm{it}}\right]
\end{aligned}
$$

In daily analysis for positive affect, results showed that partner's daily positive affect positively predicted one's own daily positive affect $(b f=.25, S E=.06, p<.001,95 \%$ CI $[.14, .36], b m=$ $.19, S E=.04, p<.001,95 \%$ CI $[.10, .28])$. In daily analysis for negative affect, results showed that partner's daily negative affect positively predicted one's own daily negative affect $(b f=$ $.26, S E=.06, p<.001,95 \%$ CI $[.14, .38], b m=.20, S E=.05, p<.001,95 \%$ CI $[.11, .29])$. These findings (see Table 1 and Table 2) indicated that individuals reported higher positive affect on the days their partners reported higher positive affect; and individuals reported higher negative affect on the days their partners reported higher negative affect.

Table 1. Partner's Positive Affect Predicting One's Own Positive Affect

\begin{tabular}{lcccc}
\hline \multicolumn{1}{c}{ Variable } & $b$ & SE & $t$ & {$[95 \% \mathrm{CI}]$} \\
\hline Intercept F & $1.99^{* * *}$ & .17 & 11.52 & {$[1.65,2.33]$} \\
Intercept M & $2.24^{* * *}$ & .14 & 16.03 & {$[1.97,2.52]$} \\
Positive Affect F & $.25^{* * *}$ & .06 & 4.45 & {$[.14, .36]$} \\
Positive Affect M & $.19^{* * *}$ & .04 & 4.39 & {$[.10, .28]$} \\
\hline
\end{tabular}

${ }^{*} p<.05, * * p<.01, * * * p<.001$.

Table 2. Partner's Negative Affect Predicting One's Own Negative Affect

\begin{tabular}{lcccc}
\hline \multicolumn{1}{c}{ Variable } & $b$ & $\mathrm{SE}$ & $t$ & {$[95 \% \mathrm{CI}]$} \\
\hline Intercept $\mathrm{F}$ & $1.22^{* * *}$ & .12 & 10.55 & {$[.99,1.45]$} \\
Intercept M & $1.30^{* * *}$ & .09 & 13.67 & {$[1.11,1.49]$} \\
Negative Affect F & $.27^{* * * *}$ & .06 & 4.35 & {$[.14, .38]$} \\
Negative Affect M & $.20^{* * *}$ & .05 & 4.40 & {$[.11, .29]$} \\
\hline${ }^{*} p<.05, * * p<.01,{ }^{* * *} p<.001$ & & & &
\end{tabular}


To examine whether changes in partner's positive and negative affect predict one's own changes in positive and negative affect, we used standardized residualized change scores for both partners. We regressed the current day's positive affect scores on the previous day's positive affect scores to create the change score for positive affect, and the current day's negative affect scores on the previous day's negative affect scores to create the change score for negative affect. Similar to the daily analyses, we used models with two random intercepts and two random slopes. The equations for the models were as following:

$$
\begin{aligned}
& \mathrm{PAChn}_{\mathrm{it}}=\text { female dummy }_{\mathrm{it}}\left[\pi_{\mathrm{f0i}}+\pi_{\mathrm{mli}}(\mathrm{PAChn})_{\mathrm{it}}\right]+\text { male dummy }_{\mathrm{it}}\left[\pi_{\mathrm{m} 0 \mathrm{i}}+\pi_{\mathrm{fli}}(\mathrm{PAChn})_{\mathrm{it}}\right] \\
& \mathrm{NAChn}_{\mathrm{it}}=\text { female dummy }_{\mathrm{it}}\left[\pi_{\mathrm{f0i}}+\pi_{\mathrm{mli}}(\mathrm{NAChn})_{\mathrm{it}}\right]+\text { male dummy }_{\mathrm{it}}\left[\pi_{\mathrm{m} 0 \mathrm{i}}+\pi_{\mathrm{fli}}\right. \\
& \left.(\mathrm{NAChn})_{\mathrm{it}}\right]
\end{aligned}
$$

Results showed that partner's positive affect change positively predicted one's own positive affect change ( $b f=.16, S E=.08, p=.034,95 \%$ CI $[.01, .31], b m=.13, S E=.06, p=.043,95 \%$ CI $[.00, .25])$. However, partner's negative affect change did not predict one's own negative affect change $(b f=.12, S E=.07, p=.081,95 \%$ CI $[-.02, .26], b m=.09, S E=.05, p=.088$, 95\% CI $[-.01, .19])$, see Table 3 and Table $4 .$. These results indicated that when partners' positive affect change, individuals' positive affect also change. However, individuals' negative affect change is independent from their partners' negative affect change.

To make sure that these findings are unique to romantic couples and to eliminate the possibility of coregulation observation in any random couples, we built a new dataset using the same dataset with randomly assigning individuals to couples. Then, we tested the exact models as in analyses for romantic couples. Results showed no significant association between the variables in any of these models. Overall, these results partially supported our hypothesis; as couples coregulated their positive emotions whereas they did not coregulate their negative emotions.

Table 3. Partner's Positive Affect Change Predicting One's Own Positive Affect Change

\begin{tabular}{lcccc}
\hline \multicolumn{1}{c}{ Variable } & $b$ & $\mathrm{SE}$ & $t$ & {$[95 \% \mathrm{CI}]$} \\
\hline Intercept F & -.03 & .13 & -.25 & {$[-.28, .22]$} \\
Intercept M & .03 & .12 & .24 & {$[-.21, .27]$} \\
Positive Affect Change F & $.16^{*}$ & .08 & 2.16 & {$[.01, .31]$} \\
Positive Affect Change M & $.13^{*}$ & .06 & 2.10 & {$[.00, .25]$} \\
\hline
\end{tabular}

${ }^{*} p<.05, * * p<.01, * * * p<.001$.

Table 4. Partner's Negative Affect Change Predicting One's Own Negative Affect Change

\begin{tabular}{lcccc}
\hline \multicolumn{1}{c}{ Variable } & $b$ & SE & $t$ & {$[95 \% \mathrm{CI}]$} \\
\hline Intercept F & .04 & .12 & .30 & {$[-.20, .27]$} \\
Intercept M & .02 & .11 & .16 & {$[-.21, .24]$} \\
Negative Affect Change F & .12 & .07 & 1.77 & {$[-.02, .26]$} \\
Negative Affect Change M & .09 & .05 & 1.79 & {$[-.01, .19]$} \\
\hline
\end{tabular}

${ }^{*} p<.05, * * p<.01, * * * p<.001$.

\section{Discussion}

In the present study, our aim was to investigate coregulation patterns of normative romantic partners' emotions in a Turkish sample by replicating previous studies. For this purpose, we also would like to provide evidence for coregulation in romantic partners. To this end, we observed the associations between partners' affect via daily diary method. Our study demonstrated that partners' daily affect predicted one's own daily affect. Moreover, changes in 
partners' positive affect predicted the changes in one's own positive affect. Contrary to expectation, we did not find a significant link between changes in partners' negative affect. However, despite the insignificance, there is a trend in this hypothesized relationship. Small sample size might be the reason of insignificance. Nevertheless, these findings suggested that our hypothesis was partially supported. To increase the validation of our significant findings, we built a sample with assigning individuals to random couples and re-tested our hypothesis. As expected, we did not find any significant association between random partners' affects.

The present work contributes to literature with providing additional evidence for emotional coregulation among romantic dyads. Prior literature suggests the existence of emotional coregulation pattern for individuals in romantic relationships (Butler 2011; 2015; Butner et al. 2007; Saxbe \& Repetti 2010; Sbarra \& Hazan 2008), however, as mentioned previously, studies investigating coregulation involve some contradictions (e.g. Saxbe \& Repetti 2010; Steele \& Ferrer 2011; Bruder et al. 2012; Sels et al. 2016). Due to this incongruence of existing studies, re-examination of coregulation patterns of romantic couples is a significant contribution for the field. Some of our findings were in line with the previous work (e.g. Anderson et al. 2003; Rohrbaugh et al. 2009; Steele \& Ferrer 2011) and demonstrated coregulation of positive emotions. However, we could not observe coregulation in negative affect. Still, our findings supported the idea that emotional coregulation is unique to people and their significant others such as parent-infant and romantic partners (see Butler 2001), as neither daily analyses nor analyses with change scores among random couples provided any evidence of coregulation.

One other beneficial aspect of our research is its replication value for coregulation studies. Recently, replication studies in psychology research started to gain major importance (for a detailed discussion see Zwaan et al. 2018). In that sense, our study can be perceived as a replication attempt for Butner and colleagues' (2007) research as they are remarkably similar in terms of both theoretical approach and methodology. Our study replicated the Butner and colleagues' (2007) findings regarding coregulation in positive affect, however we could not replicate the findings regarding coregulation in negative affect. One possible explanation for this situation may be the sample characteristics. Specifically, our sample had an average relationship length of 21 months, whereas the sample in Butner and colleagues' (2007) research had an average relationship length of 5 years. This difference in average length of relationships between samples could be the main reason behind failure in replication of their findings as mutual adjustment and awareness could be more likely to happen within long-term relationships (Butner et al. 2007).

Another contribution to the field is the usage of daily diary method. The previous work in the emotion regulation field suggested that emotions of romantic dyads are interpersonal temporal systems (Butler 2017, 1), and partners' emotional interdependence can best be observed in time (Butler 2011, 20). Hence, daily diary studies might be the best method to examine individuals' emotion regulation patterns with permitting to take both the temporal changes into account and their longitudinal aspects. Considering limited number of daily diary studies examining coregulation, the present study extends the body of work in this area.

The last contribution of the present work is exploring the emotional interdependence patterns of romantic couples in Turkish culture. In a different cultural setting, we did replicate previous findings, suggesting positive emotions are standard patterns of coregulation among romantic couples. As suggested in previous work (see Sels et al. 2016), romantic partners' emotional interdependence could be moderated by culture. Although cultural comparisons or cultural variations were not included in the present study, future national studies could focus on cultural factors in coregulation patterns.

Along with these contributions, our work has some limitations that should be considered. First limitation of the study is size of the sample used. Considering the difficulties in gathering longitudinal data from dyadic couples, the limited number of individuals ( $\mathrm{N}=37$ couples) was 
understandable, however, it is still far from ideal. For reasons of generalizability, future studies might try to replicate our findings with a larger sample. Additionally, the sample in our study mostly consisted of non-married and non-cohabiting couples at a relatively young age, which restricts external validity of study findings. Also, one of the main reasons we could not observe coregulation in couples' negative affect change might be the nature of our sample. Married or cohabiting couples spend more time together, increasing the probability for mutual contact and emotion contagion. Prior work showed that couples' covariation in their affect is stronger on the days they spend more time together (Butner et al. 2007). In that sense, future studies might consider including both cohabiting and non-cohabiting couples to observe the regulation patterns better.

Another significant limitation in the present study is the third variable problem. A shared event experienced by couples may affect their reactions similarly. One of the mechanisms in affective process theory (see Elfenbein 2014) suggests that resembling emotions occur when individuals share the same affective experience. Also, after experiencing a shared emotional event, dyads may co-construct emotional meaning and share similar reactions to future emotional events (Butler 2015, 3-4). Thus, in future studies, researchers may focus on measuring couples' affective reactions to specific events and design studies accordingly.

One other limitation is the correlational nature of findings in the study. Although we collected data with daily diary method and conducted longitudinal analyses, it should not be forgotten that our findings are still correlational. To specify causal directions among emotion regulation patterns of romantic partners, studies with experimental procedures are needed.

The last limitation of the study is the wide range of participants' relationship duration. As romantic relationships progress, satisfaction derived from them declines over time (Clements et al. 1997; Mitnick et al. 2009). Similar effect of relationship duration may be valid for strength of coregulation between romantic partners as well. As sample's relationship duration becomes more spread, especially in small sample sizes, it makes harder comparing couples within early phases of their relationships with more established couples. Future research with larger sample sizes would benefit from comparing coregulation patterns of couples in different phases of their relationship.

In conclusion, our study replicated previous findings and provided further evidence for emotional coregulation among normative romantic couples. It seems that coregulation especially in positive emotions- is the standard pattern of emotion regulation for individuals in romantic relationships. 


\section{REFERENCES}

Anderson C., Keltner D. \& John O. P. (2003). "Emotional convergence between people over time". Journal of Personality and Social Psychology 84/5 (2003) 1054-1068. doi: 10.1037/00223514.84.5.1054

Beckes L. \& Coan J. A. (2011). "Social baseline theory: The role of social proximity in emotion and economy of action". Social and Personality Psychology Compass 5/12 (2011) 976-988. doi: 10.1111/j.1751-9004.2011.00400.x

Beebe B., Messinger D., Bahrick L. E., Margolis A., Buck K. A. \& Chen H. (2016). “A system view of mother-infant face-to-face communication". Developmental psychology 52/4 (2016) 556-571. doi: $10.1037 / \mathrm{a} 0040085$

Bolger N. \& Shrout P. E. (2007). "Accounting for statistical dependency in longitudinal data on dyads". Modeling Contextual Effects in Longitudinal Studies (2007) 285-298.

Bradbury T. N., Fincham F. D., \& Beach S. R. (2000). "Research on the nature and determinants of marital satisfaction: A decade in review". Journal of marriage and family 62/4 (2000) 964-980.

Bruder M., Dosmukhambetova D., Nerb J. \& Manstead A. S. (2012). "Emotional signals in nonverbal interaction: Dyadic facilitation and convergence in expressions, appraisals, and feelings". Cognition \& Emotion 26/3 (2012) 480-502. doi:10.1080/02699931.2011.645280

Butler E. A. (2011). "Temporal interpersonal emotion systems: The "TIES" that form relationships". Personality and Social Psychology Review 15/4 (2011) 367-393. doi: 10.1177/1088868311411164

Butler E. A. (2015). "Interpersonal Affect Dynamics: It Takes Two (and Time) to Tango". Emotion Review (2015) Advance online publication. doi: 10.1177/1754073915590622

Butler E. A. (2017). "Emotions are temporal interpersonal systems". Current opinion in psychology 17 (2017) 129-134. doi: 10.1016/j.copsyc.2017.07.005

Butler E. A. \& Randall A. K. (2013). "Emotional coregulation in close relationships". Emotion Review 5 (2013) 202-210. doi: 10.1177/1754073912451630

Butner J., Diamond L. M. \& Hicks A. M. (2007). "Attachment style and two forms of affect coregulation between romantic partners". Personal Relationships 14/3 (2007) 431-455. doi: 10.1111/j.14756811.2007.00164.x

Clements M., Cordova A. D., Markman H. J. \& Laurenceau J. P. (1997). "The erosion of marital satisfaction over time and how to prevent it”. Eds. R. J. Sternberg \& M. Hojjat, Satisfaction in close relationships. New York (1997) 335-355.

Cranford J. A., Shrout P. E., Iida, M., Rafaeli E., Yip T. \& Bolger N. (2006). “A procedure for evaluating sensitivity to within-person change: Can mood measures in diary studies detect change reliably?". Personality and Social Psychology Bulletin 32 (2006) 917-929. doi: 10.1177/ 0146167206287721

Diamond L. M. \& Aspinwall L. G. (2003). "Emotion regulation across the life span: An integrative perspective emphasizing self-regulation, positive affect, and dyadic processes". Motivation and Emotion 27/2 (2003) 125-156. https://doi.org/10.1023/A:1024521920068

Elfenbein H. A. (2014). "The many faces of emotional contagion: An affective process theory of affective linkage". Organizational Psychology Review 4/4 (2014) 326-362. https://doi.org/10.1177/ 2041386614542889

Feldman R. (2003). "Infant-mother and infant-father synchrony: The coregulation of positive arousal". Infant Mental Health Journal: Official Publication of The World Association for Infant Mental Health 24/1 (2003) 1-23. doi: 10.1002/imhj.10041

Fischer M. S., Baucom, D. H., Baucom, B. R., Abramowitz, J. S., Kirby, J. S. \& Bulik, C. M. (2017). "Disorder-specific patterns of emotion coregulation in couples: Comparing obsessive compulsive disorder and anorexia nervosa". Journal of Family Psychology 31 (2017) 304-315. https://doi.org/10.1037/fam0000251

Feldman R. (2015). "Mutual influences between child emotion regulation and parent-child reciprocity support development across the first 10 years of life: implications for developmental psychopathology". Development and psychopathology 27/4pt1 (2015) 1007-1023. doi:10.1017/S0954579415000656

Gottman J. M. (1993). “A theory of marital dissolution and stability”. Journal of family psychology 7/1 (1993) 57-75.

Gök A. C., Selçuk E. \& Gençöz T. (2018). "Olumlu ve olumsuz duygulanımın tekrarlanan ölçümlerde kişi-içi güvenilirliği”. Türk Psikoloji Dergisi 33 (2018) 53-64. 
Hazan C., Gur-Yaish N. \& Campa M. (2004). "What does it mean to be attached?”. Eds. W. S. Rholes \& J. A. Simpson, Adult attachment: New directions and Emerging Issues. New York (2004) 55-85.

Helm J. L., Sbarra D. A. \& Ferrer E. (2012). "Assessing cross-partner associations in physiological responses via coupled oscillator models". Emotion 12/4 (2012) 748-762. http://dx.doi.org/10.1037/ a0025036

Helm J. L., Sbarra D. A. \& Ferrer E. (2014). "Coregulation of respiratory sinus arrhythmia in adult romantic partners". Emotion 14 (2014) 522-531. doi: 10.1037/a0035960.

Keltner D. \& Haidt J. (1999). "Social functions of emotions at four levels of analysis". Cognition \& Emotion 13/5 (1999) 505-521.

Lunkenheimer E., Tiberio S. S., Buss K. A., Lucas-Thompson R. G., Boker S. M. \& Timpe Z. C. (2015). "Coregulation of respiratory sinus arrhythmia between parents and preschoolers: Differences by children's externalizing problems”. Developmental psychobiology 57/8 (2015) 994-1003. doi: 10.1002/dev.21323

Mitnick D. M., Heyman R. E., \& Smith Slep A. M. (2009). "Changes in relationship satisfaction across the transition to parenthood: A meta-analysis". Journal of Family Psychology, 23, 848-852. doi: $10.1037 / \mathrm{a} 0017004$

Ong A. D., Gardner, S., Urganci, B., Gunaydin, G. \& Selcuk, E. (2019, August 29). "Affective Reactivity, Resting Heart Rate Variability, and Marital Quality: A 10-Year Longitudinal Study of U.S. Adults". Journal of Family Psychology (2019). Advance online publication. http://dx.doi.org/10.1037/fam0000591

Randall A. K. \& Butler E. A. (2013). "Attachment and emotion transmission within romantic relationships: Merging intrapersonal and interpersonal perspectives". Journal of Relationships Research 4/e10 (2013) 1-10. doi 10.1017/jrr.2013.10

Reed R. G., Barnard K. \& Butler E. A. (2015). "Distinguishing emotional coregulation from codysregulation: An investigation of emotional dynamics and body-weight in romantic couples". Emotion 15/1 (2015) 45-60. doi: 10.1037/a0038561

Reed R. G., Randall A. K., Post J. H. \& Butler E. A. (2013). "Partner influence and in-phase versus antiphase physiological linkage in romantic couples". International Journal of Psychophysiology 88/3 (2013) 309-316. https://doi.org/10.1016/j.ijpsycho.2012.08.009

Reis H. T. (2013). "Relationship well-being: The central role of perceived partner responsiveness". Eds. C. Hazan \& M. I. Campa, Human bonding: The science of affectional ties. New York (2013) 283-307.

Reis H. T. \& Shaver P. (1988). "Intimacy as an interpersonal process". Handbook of personal relationships 24/3 (1988) 367-389.

Rohrbaugh M. J., Shoham V., Butler E. A., Hasler B. P., \& Berman J. S. (2009). “Affective synchrony in dual-and single-smoker couples: Further evidence of "symptom-system fit"?. Family Process 48/1 (2009) 55-67.

Saxbe D. \& Repetti R. L. (2010). "For better or worse? Coregulation of couples' cortisol levels and mood states". Journal of Personality and Social Psychology 98/1 (2010) 92-103. doi: 10.1037/a0016959

Sbarra D. A. \& Coan J. A. (2018). "Relationships and health: The critical role of affective science". Emotion Review 10/1 (2018) 40-54. https://doi.org/10.1177/1754073917696584

Sbarra D. A. \& Hazan C. (2008). "Coregulation, dysregulation, self-regulation: An integrative analysis and empirical agenda for understanding adult attachment, separation, loss, and recovery". Personality and Social Psychology Review 12/2 (2008) 141-167. doi:10.1177/1088868308315702

Schoebi D. \& Randall A. K. (2015). "Emotional dynamics in intimate relationships". Emotion Review 7/4 (2015) 342-348. doi: 10.1177/1754073915590620

Sels L., Ceulemans E., Bulteel K. \& Kuppens P. (2016). "Emotional interdependence and well-being in close relationships". Frontiers in psychology 7 (2016) 283. https://doi.org/10.3389/fpsyg.2016.00283

Steele J. S. \& Ferrer E. (2011). "Latent differential equation modeling of self-regulatory and coregulatory affective processes". Multivariate Behavioral Research 46/6 (2011) 956-984. doi: 10.1080/ 00273171.2011 .625305

Tronick E. Z. (1989). "Emotions and emotional communication in infants". American psychologist 44/2 (1989) 112-119.

Watson D., Clark L. A., \& Tellegen A. (1988). "Development and validation of brief measures of positive and negative affect: the PANAS scales". Journal of personality and social psychology 54/6 (1988) 1063-1070.

Zaki J., \& Williams W. C. (2013). “Interpersonal emotion regulation”. Emotion 13/5 (2013) 803-810. doi: $10.1037 / \mathrm{a} 0033839$

Zwaan R. A., Etz A., Lucas R. E. \& Donnellan M. B. (2018). "Making replication mainstream". Behavioral and Brain Sciences, 41/e120 (2018) doi:10.1017/S0140525X17001972 